\title{
中国の活性炭工業の現状
}

(平成 5 年 9 月 17 日受理)

\section{Activated Carbon Industry in China}

\section{Shangyu Gao}

\section{1.はじめに}

近年来, 中国の活性炭工業は大きな発展を迎えた。活 性炭の生産量がだんだん増えてきただけでなく, 活性炭 の研究に携わる人も多くなった。また, 中国の大学は専 攻が細かく分かれており, 活性炭関保の専攻もある。し たがって中国の活性炭工業は活性炭の製造から，その教 育や科学研究に至るところまで自分のシステムを持って いるとも言える。今後, 中国活性炭工業は一層発展して いくことが望まれるだろう。

ところが, 中国の活性炭工業においてはその急速な発 展に伴う問題が少なくない。たとえば数多くの活性炭製 造工場には生産性の低下, 労働条件の悪さ, ひどい環境 污染問題がときどきあることも事実である。今後これら の問題はできるだけ早く解決すべきである。

ここに中国活性炭分野の現状について紹介する。

\section{2. 活性炭の製造}

\section{1 活性炭の生産吾}

現在，中国における活性炭製造工場は約200社以上あ る。活性炭生産能力は年間およそ10万トンである。それ らの製造工場には年間生産量が1000トン未満の中小企業 が多く，大企業はあまり多くない。

中国での活性炭生産量の推移を Table 1に示す1)。1992 年の中国の活性炭生産量は約7万トンに達した。Table

中国南京林業大学化学工程学院: 南京市 210037 , 中華人 民共和国

本資料は活性炭技術研究会第 89 回講演会での講演内容を まとめたものである。
Table 1 中国での活性炭生産量の推移

\begin{tabular}{|c|c|}
\hline 年度 & 活性炭生産量（万トン） \\
\hline 1950 & 0.01 \\
\hline 1981 & 1. 2 \\
\hline 1983 & $3 \cdot 5$ \\
\hline 1987 & 4. 5 \\
\hline 1991 & 6 \\
\hline 1992 & 7 \\
\hline
\end{tabular}

1から分かるように, 1981年以降, 中国の活性炭生産量 が急速に増加している。これは主に中国の工業発展につ れて活性炭に対する需要量が増えたためである。また， 活性炭の輸出量の増加もその原因の一つである。

つぎに1992年を例として活性炭の年間生産量の内訳を Table 2に示す1)。Table 2に示すように，今，中国では 活性炭の生産には薬品賦活法とガス賦活法の両方が使わ れており，木質系原料および粉末活性炭の生産量がやや 多い。ところが, 最近の活性炭生産の伸び率から見る と, 石炭を原料とする成型活性炭の方が大きい。現在, 中国では石炭を原料とする活性炭工場は年間 6 万トンく らいの生産能力を持っている。

\section{2 活性炭の製造法}

\subsection{1 ガス賦活法}

(1) 原料

石炭: 中国は世界一の石炭生産国である。活性炭の原料 に適する石炭は主に寧夏回族自治区や内蒙古などの省区 から採れる。その中では寧夏に属する太西というところ で出産する太西石炭が一番有名である。その石炭の成分 
Table 2 1992年の中国の活性炭生産量の内訳

\begin{tabular}{|l|l|c|}
\hline \multicolumn{2}{|c|}{ 項目 } & 活性炭生産量 (万トン) \\
\hline 原料別 & $\begin{array}{l}\text { 木質系原料活性炭 } \\
\text { 石炭系原料活性炭 }\end{array}$ & 約 4 \\
& 約 3 \\
\hline \multirow{2}{*}{ 賦活方法別 } & 薬品賦活法活性炭 & 約 3.5 \\
& カ賦活法活性炭 & 約 3.5 \\
\hline \multirow{2}{*}{ 形状別 } & 粉末活性炭 & 約 4 \\
& 顆粒活性炭 & 約 3 \\
\hline & 合計 & 約 7 \\
\hline
\end{tabular}

Table 3 太西石炭の成分分析の一例

\begin{tabular}{|c|c|c|}
\hline \multicolumn{2}{|c|}{} & \multicolumn{2}{|c|}{ 分析結果 $(\mathrm{w} t \%)$} \\
\hline \multirow{2}{*}{ 工業分析 } & $\begin{array}{l}\text { 揮発分 } \\
\text { 灰分 }\end{array}$ & $\begin{array}{l}6.5 \sim 9.5 \\
3\end{array}$ \\
\hline \multirow{2}{*}{ 元素分析 } & $\mathrm{C}$ & $92 \sim 90$ \\
& $\mathrm{H}$ & $\begin{array}{l}3.5 \sim 3.8 \\
0.2 \sim 0.3\end{array}$ \\
\hline
\end{tabular}

分析の一例をTable 3 に示す2)。

堅果殼: ヤシ款, 杏の種殼および胡桃殼がよく使われい る。

木炭: 松木炭およびその他

(2) 賦活郕

水蒸気, 燃焼ガス, 空気

(3) ガス賦活炉

$\begin{array}{ll}\text { 移動床炉 } & 200 \sim 1000 \text { トン/基, 年 } \\ \text { 多管炉 } & 100 \sim 150 \text { トン/基, 年 } \\ \text { 流動層炉 } & 100 \sim 300 \text { トン/基, 年 } \\ \text { Herreshoff 型多段床炉 } 1000 \text { トン/基, 年 } \\ \text { その他 }\end{array}$

\subsection{2 䓦品賦活法}

(1) 原料

鋸首, 砂糖きびの涬など

(2) 賦活剂

塩化亚鉛, りん酸

(3) 薬品賦活炉

ロータリーキルン，平板炉

\subsection{3 主な活性炭製造工場}

主な活性炭製造工場をTable 4に示す3)。各工場の所在 地をFig.1に示す。

\section{3. 活性岸の応用}

\section{1 中国の活性炭の命名}

周知のように活性炭は出発原料, 賦活方法, 外観形状 などが異なっているため沢山の種類がある。以前, 中国 の活性炭はそれぞれの製造工場で名付けられたので大変 混乱していた。それを統一するため, 1990年, 国が活性 炭の命名方法を発布した。その方法に基づいた活性炭の 名称はつぎのような三つの部分から構成されている4)。

ここで，甲は出発原料を表すローマ字(Table 5)，乙は 賦活方法を表すローマ字(Table 6), 丙は活性炭の外形を 表すローマ字(Table 7), および活性炭の寸法を表す数字 (Table 8)である。

例えば，ZHFは木質系原料で薬品賦活によって製造さ れた粉末活性炭を表している。MWY15は石炭系原料で ガス賦活によって製造された直径 $1.5 \mathrm{~mm}$ の円柱状活性炭 を示している。また，GWB35×59は堅果殼を原料として ガス賦活によって製造された粒度範囲0.35 0.59mmの破 砕状顆粒活性炭を示している。

ところが，上述の活性炭命名方法を発布してからもう 3年になったにもかかわらず，今迄まだきびしく実行さ れていない。

\section{2 活性炭の応用}

\section{2 .1 粉末活性炭}

中国の粉末活性炭はほとんど木質系原料によって製造 され，主な種類はつぎのようである。

(1) 糖用粉末活性炭

糖用粉末活性炭は木質系原料で薬品賦活によって製造 され，その粒度はふつう 200 メッシュ (76 $\mu \mathrm{m})$ 以下であ る。これは中国の活性炭の中では生産量の一番多いもの であり，主にブドウ糖やデンプン糖の糖液脱色精製に使 われている。そして，これも中国から輸出している活性 
Table 4 中国の主な活性炭製造工場

\begin{tabular}{|c|c|c|c|c|}
\hline & 工場 & 生産能力 & 活性炭品種 ${ }^{*}$ & 賦活方法** \\
\hline (1) & 北京光華木材工場 & 1500 & $G, P$ & $\mathrm{~A}$ \\
\hline 2 & 懐玉山活性炭工場 & 5000 & $P, G$ & $\mathrm{~B}, \mathrm{C}, \mathrm{A}$ \\
\hline (3) & 上海活性炭工場 & 4000 & $P, G$ & $\mathrm{~B}, \mathrm{~A}$ \\
\hline (4) & 杭州木材工場 & 4000 & $\mathrm{P}$ & $\mathrm{B}$ \\
\hline (5) & 新崗山活性炭工場 & 3000 & $\mathrm{P}$ & $\mathrm{B}$ \\
\hline 6 & 浦城林業化学工場 & 2500 & $P, G$ & A \\
\hline (1) & 遂昌林業化学工場 & 2500 & $\mathrm{P}$ & A \\
\hline (3) & 赤峰活性炭工場 & 1000 & $G, P$ & $\mathrm{~A}$ \\
\hline 9 & 天全活性炭工場 & 1000 & $\mathrm{P}$ & B \\
\hline (11) & 溧陽活性炭工場 & 1000 & $P, G$ & $B, A$ \\
\hline (11) & 建新活性炭工場 & 1000 & $G, P$ & $\mathrm{~A}$ \\
\hline (1) & 海浜活性炭工場 & 1000 & $G, P$ & $\mathrm{~A}$ \\
\hline (19) & 新華化学工場 & 8000 & $\mathrm{G}$ & $\mathrm{A}$ \\
\hline (4) & 石嘴山炭素工場 & 2000 & $\mathrm{G}$ & $\mathrm{A}$ \\
\hline
\end{tabular}

* G : 顆粒活性炭, P : 粉末活性炭

** A : ガス賦活法, $\mathrm{B}:$ 塩化亜鉛賦活法, C : クん酸賦活法

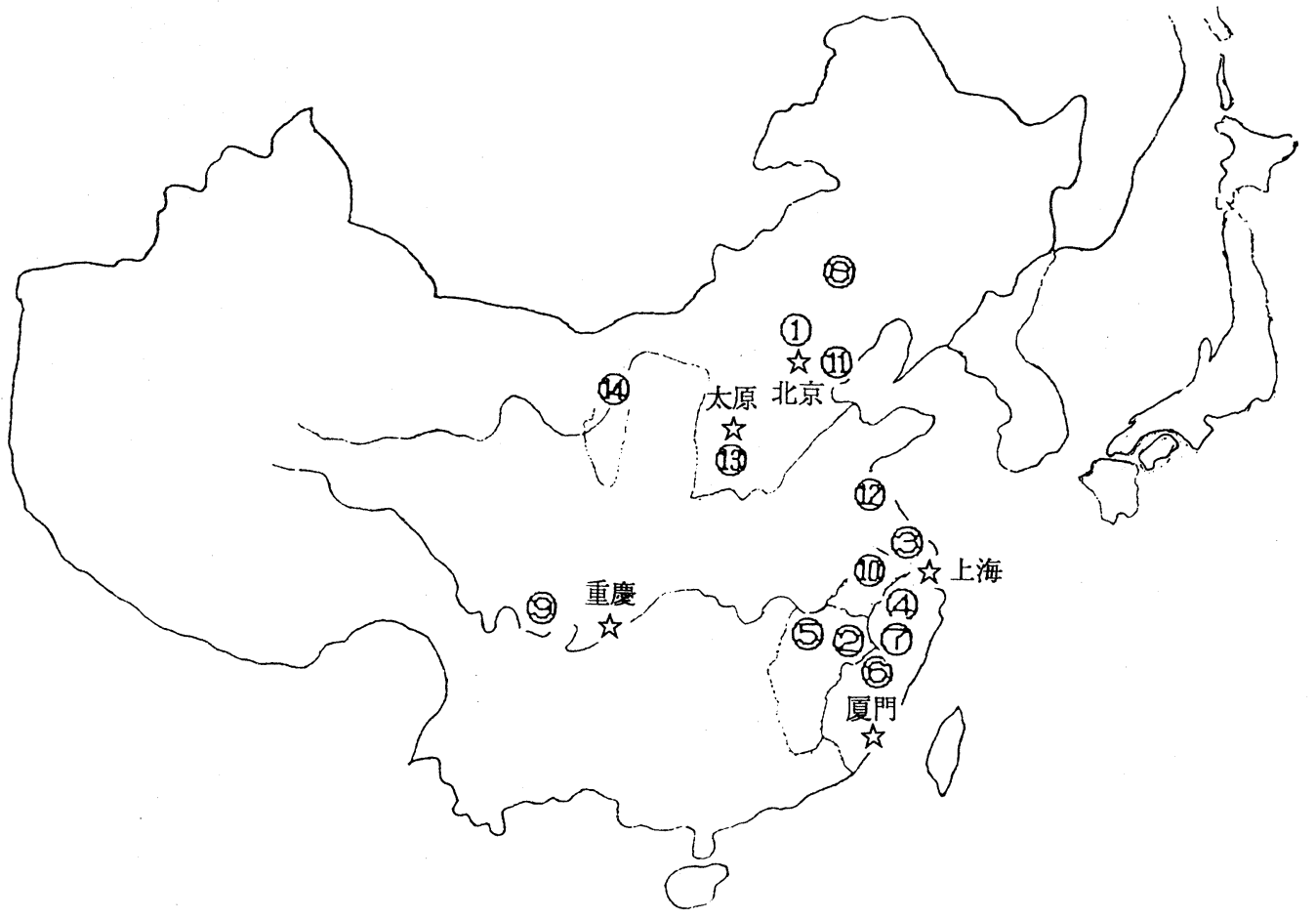

Fig.1 中国の活性炭工場

(図中の番号はTable 4 の番号に同じ) 
炭の主な炭種である。中国糖液脱色用木質粉末活性炭の 規格をTable 9に示す5)。

(2) 薬用粉末活性炭

薬用粉末活性炭は木質系原料から薬品賦活あるいはガ ス賦活によって製造され，その粒度は200メッシュ以下 になっている。この活性炭は主に医薬品や工業薬品の脱 色精製のため，それらの製造プロセスに使われている。 また，使用対象の特徵に応じていろいろな専用炭種が製 造されている。例えば, 注射薬専用活性炭とかビ夕ミン C 専用活性炭とかがある。

(3) 工業用粉末活性炭

Table 5 出発原料を表すローマ字

\begin{tabular}{|c|l|}
\hline ローマ字 & \multicolumn{1}{|c|}{ 出発原料 } \\
\hline $\mathrm{Z}$ & 木質系原料 \\
$\mathrm{G}$ & 堅果款 (ヤシ款, 杏の種殼など $)$ \\
$\mathrm{M}$ & 石炭系原料 \\
$\mathrm{J}$ & 使用済の老廃活性炭 \\
\hline
\end{tabular}

Table 6 賦活方法を表すローマ字

\begin{tabular}{|c|c|}
\hline ローマ字 & 賦活方法 \\
\hline$H$ & 薬品賦活法 \\
$W$ & ガス賦活法 \\
\hline
\end{tabular}

Table 7 活性炭の外形を表すローマ字

\begin{tabular}{|c|l|}
\hline ローマ字 & \multicolumn{1}{|c|}{ 活性炭の外形 } \\
\hline $\mathrm{F}$ & 粉末活性炭 \\
$\mathrm{B}$ & 破磔状顆粒炭 \\
$\mathrm{Y}$ & 円柱状 (ペレット状) 成型炭 \\
$\mathrm{O}$ & 球形活性炭 \\
\hline
\end{tabular}

工業用粉末活性炭は主に木質系原料から薬品賦活ある いはガス賦活によって製造され，グルタミン酸ナトリウ ムや清酒や清涼飲料水などの食料品工業, 水処理などの 領域に使われている。

\subsection{2 顆粒活性炭}

(1) 破砕状顆粒炭

破砕状顆粒活性炭は主にヤシ殼などの堅果殼を原料と してガス賦活によって製造されている。この活性炭の主 な用途は触媒担体，金の回収および上水処理などであ る。

(2) 成型顆粒炭

成型活性炭はほとんど良質の石炭を原料としてガス賦 活によって製造された円柱型(ペレット状)の顆粒炭であ る。これは空気浄化, 溶剂回収, 水処理, 排煙脱硫およ びガスマスクなど数多くの分野に使われている。

\section{3 活性炭の価格}

近年来，中国においては活性炭を製造する出発原料や 化学薬品がインフレの影響によって值上げされ，そのた め活性炭の販売価格が上昇している。1993年現在の中国 における活性炭の販売価格をTable 10に示す6)。勿論, 同一類別の活性炭でも吸着能力や不純物含量などによっ て販売価格が異なっている。例えば，木質系粉末活性炭 では前に述べた注射薬専用活性炭が一番值段が高い。

\section{4 活性炭の貿易}

中国では活性炭の輸入と輸出の両方が行われている。 輸入しているのは少量の専用炭種であり, 活性炭輸入量 に比へて輸出量が多い。輸出量については正確に統計す ることは難しいが，この数年たんたん増えてくる傾向が ある。1992年にはその輸出量は約1万トンに達したとい う報告がある1)。輸出した活性炭は主に糖液脱色用木質 粉末活性炭である。最近, 成型活性炭を輸出したことも ある。

中国の活性炭メーカーには活性炭輸出に強い意欲を もっているところがいくつかある。

\section{4. 活性炭の学術活動}

中国においては活性炭研究に携わるところが数多くあ

Table 8 活性炭の寸法を表す数字

\begin{tabular}{|l|c|c|l|}
\hline \multicolumn{1}{|c|}{ 活性炭外形 } & 標記方法 & 実例 & \multicolumn{1}{|c|}{ 備考 } \\
\hline 破砕状 & 下限 $\times$ 上限 & $35 \times 59$ & 粒度範囲 $0.35 \sim 0.59 \mathrm{~mm}$ \\
円柱状 & 直径 & 15 & 直径 $1.5 \mathrm{~mm}$ \\
球形 & 直径 & 20 & 直径 $2 \mathrm{~mm}$ \\
\hline
\end{tabular}


Table 9 糖液脱色用木質粉末活性炭の規格

\begin{tabular}{|c|c|c|c|c|}
\hline \multirow[t]{2}{*}{ 項目 } & \multicolumn{4}{|c|}{ 規格 } \\
\hline & & 特級品 & 一級品 & 合格品 \\
\hline カラメル脱色力， \% & & & & \\
\hline A 法 & $\geqq$ & 100 & 90 & 80 \\
\hline B 法 & $\geqq$ & 100 & 90 & 80 \\
\hline 乾燥減量，\% & $\leqq$ & 10.0 & 10.0 & 10.0 \\
\hline $\mathrm{p} \mathrm{H}$ & & $3.5 \sim 5.0$ & $3.5 \sim 5.0$ & $3.5 \sim 5.0$ \\
\hline 酸可溶物，\% & $\leqq$ & 1.0 & 1.0 & 2.0 \\
\hline 鉄 $\left(\mathrm{Fe}^{3+}\right) ， \%$ & $\leqq$ & 0.05 & 0.10 & 0.15 \\
\hline 塩化物（Clとして），\% & $\leqq$ & 0.20 & 0.25 & 0.30 \\
\hline 強熱残分，\% & $\leqq$ & 3.0 & 4.0 & 5.0 \\
\hline
\end{tabular}

Table 10 中国における活性炭販売価格

\begin{tabular}{|l|c|c|c|}
\hline \multirow{2}{*}{ 活性炭の類別 } & \multicolumn{2}{|c|}{ 販売価格 } & \multirow{2}{*}{ 備考 } \\
\cline { 2 - 4 } & 元 /トン & 万円 & \\
\hline 粉末活性炭 & $6000 \sim 10000$ & $12 \sim 20$ & 木質系原料 \\
成型顆粒炭 & $4000 \sim 8000$ & $8 \sim 16$ & $\begin{array}{c}\text { 炭系原料 } \\
\text { 堅果殼原料 }\end{array}$ \\
\hline 破砕状顆粒炭 & $10000 \sim 30000$ & $20 \sim 60$ & \\
\hline
\end{tabular}

る。全国的な学術組織は中国林学会林産化学化工学会活 性炭専門委員会がある。この活性炭専門委員会は活性炭 工場, 研究所および大学などによって構成され，13人の 委員を持っている。筆者は1991年からその委員会の副主 任委員になっている。

活性炭専門委員会は中国活性炭の生産, 販売および直 面している問題を調べて協調する他に，中国活性炭学術 討論会を主催することがおもな仕事である。1981年から 1991年にかけて重慶, 太原, 北京, 上海において第1回 から4回までの中国活性炭学術討論会を主催した。そし て第5回の討論会は初めて日本, アメリカ, ロシアなど 外国人学者を招待し，1996年に北京あるいは厦門で開催 することにしだ)。

中国の改革開放国策をとってから活性炭分野は海外と の学術交流が活発になってきた。今迄に，ロシア学者 $\mathbf{M}$. M. Dubininや日本活性炭技術研究会会長 北川睦夫博士
などを招待して中国で講演していただいている。特に北 川睦夫博士の2回にわたる中国での講演は評判が高かっ た。そして中国からもいくつかの代表団を組織し, 西ド イッ,オランダ，ロシア，フィリピンなどの国へ派遣 し，活性炭関係の視察をしたことがある。

\section{文献}

1) 韓振先, 林産化工通訊 1993 [No.1], 29.

2) 安豊剛, 活性炭 1989 [No.1], 57.

3）第二届活性炭専業委員会第二回会議資料による, (1992).

4) 中国国家標準, GB-12495-90, 活性炭型号命名法, (1990).

5) 中国国家標準(発布中), 糖液脱色用木質粉末活性炭.

6) 施蔭鋭, 王瑛, 全国活性炭調査報告 (内部資料), (1993). 